\title{
CARDIOVASCULAR HAEMODYNAMICS DURING ENFLURANE-PANCURONIUM ANAESTHESIA IN PATIENTS WITH VALVLLAR HEART DISEASE
}

\author{
Peter Valdemar Klauber, Mogens Bredgaard Sørensen, \\ Vinni Christensen, Finn Wiberg-Jørgensen, and Per Skovsted
}

\section{INTRODUCTION}

ENFLURANE (ETHRANE ${ }^{(0)}$ ) has been shown to depress myocardial contractility in the isolated papillary muscle of cats. ${ }^{1,2}$ Also in cats enflurane has been shown to depress preganglionic sympathetic nervous acticity. ${ }^{3}$ In patients free of cardio-respiratory disease, enflurane has been shown to produce minimal cardiovascular depression, $4 . .5$ This study was carried out to evaluate the cardiovascular actions of enfluranepancuronium anaesthesia in patients with cardiac valvular disease.

\section{Material and Method}

Six patients with valvular heart disease scheduled for mitral and/or aortic valve replacement were studied. Mean age of the patients was 56 years (range $48-63$ years). Of the three women and three men that were subjects for the study, three suffered from aortic valve disease and underwent aortic valve replacement only, two patients suffered from both aortic and mitral valve disease and underwent double valve replacement, and one patient needed mitral valve replacement only. The mean cardiac index measured prior to surgery during cardiac catherization was $2.5 \mathrm{l} / \mathrm{min} / \mathrm{m}^{2}$ (range $1.7-3.81 / \mathrm{min} / \mathrm{m}^{2}$ ). All patients were in functional groups II-III (three in each group) according to the N.Y.H.A. classification.

Premedication consisted of diazepam 0.1 $\mathrm{mg} / \mathrm{kg}$ and scopolamine $0.005 \mathrm{mg} / \mathrm{kg}$ given intramuscularly two hours before induction of anaesthesia, Under local anaesthesia a radial artery was cannulated and a Swan-Ganz flow directed thermodilution catheter was inserted through the right internal jugular vein by a percutaneous technique. In addition, a central ven-

The Department of Anaesthesia, the Department of Cardiac Surgery $R$, and the Surgical Laboratory for Circulation Research D, Rigshospitalet (State University Hospital), Blegdamsvej 9,2100 Copenhagen. Denmark.

Canad. Anaesth. Soc. J., vol. 25, no. 2, March 1978 ous catheter was inserted from a cubital vein for drug injection.

The following parameters were recorded prior to induction of anaesthesia and after 15 minutes of enflurane-pancuronium anaesthesia before operation: mean arterial pressure (MAP), calculated as the diastolic pressure plus one-third of the pulse amplitude; central venous pressure (CVP), pulmonary arterial mean pressure (PAMP), pulmonary capillary wedge pressure (PCWP) (recorded using Statham P23 dbtransducers positioned in the midaxillary line of the patient placed supine on the operating table); heart rate (HR), counted from the pulse curve. The electrocardiogram was also recorded and together with the parameters mentioned above, was recorded on a Mingograph (Elema-Schoenander) 6-channel recorder. Cardiac output was measured by the thermodilution method ${ }^{6}$ by a cardiac output computer, model 9500 Edwards. The mean of three measurements of cardiac output was used for calculations. Cardiac index $(\mathrm{CI})$ was calculated using the height and weight nomogram of duBois. ${ }^{7}$

Pulmonary vascular resistance (PVR) was calculated from the formula ((PAMP - PCWP) $\times$ $80) / \mathrm{CO}$ dynes/sec/ $\mathrm{cm}^{-5}$. Systemic vascular resistance (SVR) was calculated from the formula $((\mathrm{MAP}-\mathrm{CVP}) \times 80) / \mathrm{CO}$ dynes $/ \mathrm{sec} / \mathrm{cm}^{-5}$. Stroke volume (SV) was calculated as cardiac output divided by heart rate. Blood samples were drawn from the arterial and pulmonary artery catheters and analyzed on a Radiometer ${ }^{*}$ ABL 2 electrode for $\mathrm{P}_{\mathrm{O}_{2}}, \mathrm{P}_{\mathrm{CO}_{2}}, \mathrm{pH}$, and standard bicarbonate.

Anaesthesia was induced with a sleep dose of thiopentone, mean dose $170 \mathrm{mg}$ (range 125-225 $\mathrm{mg}$ ). Tracheal intubation was performed using intravenous succinylcholine $1 \mathrm{mg} / \mathrm{kg}$. Enflurane was administered from a calibrated vaporizer (enflurotec, Cyprane) in a concentration of three per cent for eight minutes and thereafter two per cent for the remainder of the study. Pure oxygen was used as the carrying gas. Relaxation was achieved by the intravenous adminstration of pancuronium $(0.1 \mathrm{mg} / \mathrm{kg})$ and respiration was 113 
TABLE I

Haemodynamic Effects of Enflurane-Pancuronium Anaesthesia on Patients With Valvular Heart Disease. All Values are Means From Six Patients \pm Standard Errors. A Significant Change is Expressed By a p-Value

\begin{tabular}{|c|c|c|c|}
\hline & $\begin{array}{l}\text { Pre-anaesthetic } \\
\text { values }\end{array}$ & $\begin{array}{l}\text { Anaesthetic } \\
\text { values }\end{array}$ & $\stackrel{p}{p}$ \\
\hline $\begin{array}{l}\text { Mean arterial } \\
\text { pressure }(\mathrm{mm} \mathrm{Hg})\end{array}$ & $94.7 \pm 5.6$ & $88.0 \pm 6.1$ & \\
\hline $\begin{array}{l}\text { Cardiac index } \\
\left.\text { (litre } / \mathrm{m}^{2} / \mathrm{min}\right)\end{array}$ & $2.8 \pm 0.2$ & $2.5 \pm 0.2$ & $<0.01$ \\
\hline $\begin{array}{l}\text { Heart rate } \\
\text { (beats/min) }\end{array}$ & $80.0 \pm 5.6$ & $93.0 \pm 3.6$ & \\
\hline $\begin{array}{l}\text { Pulmonary capillary } \\
\text { wedge pressure (mm } \mathbf{H g} \text { ) }\end{array}$ & $11.0 \pm 1.6$ & $11.0 \pm 2.3$ & \\
\hline $\begin{array}{l}\text { Stroke volume } \\
\text { (ml/beat) }\end{array}$ & $60.0 \pm 5.6$ & $46.0 \pm 5.4$ & $<0.01$ \\
\hline $\begin{array}{l}\left(\text { dynes } / \mathrm{sec} / \mathrm{cm}^{-5}\right) \\
\text { Pulmonary arterial } \\
\text { mean pressure }(\mathrm{mm} / \mathrm{Hg})\end{array}$ & $\begin{array}{l}1566 \pm 229 \\
17.0+2.6\end{array}$ & $1642 \pm 209$ & \\
\hline $\begin{array}{l}\text { Pulmonary vascular } \\
\text { resistance } \\
\text { (dynes } / \mathrm{sec} / \mathrm{cm}^{-5} \text { ) }\end{array}$ & $114 \pm 31$ & $120 \pm 10$ & \\
\hline $\begin{array}{l}\text { Central venous } \\
\text { pressure }(\mathrm{mm} \mathrm{Hg})\end{array}$ & $7.1 \pm 1.6$ & $5.3 \pm 2.3$ & \\
\hline
\end{tabular}

controlled by a Bird mark 4 respirator using a gas flow of four litres/minute and a semiclosed circle system. The patients were ventilated with a tidal volume of $10 \mathrm{ml} / \mathrm{kg}$ at a frequency of 14 per minute. Statistical analyses were performed using paired t-test. A p-value of less than 0.05 was considered statistically significant.

\section{RESULTS}

The results of enflurane-pancuronium anaesthesia are shown in Table 1 . Cardiac index declined from $2.8 \pm 0.2$ litres $/ \mathrm{min} 102.5 \pm 0.2 \mathrm{li}$ tres $/ \mathrm{min}(\mathrm{p}<0.01)$. This was due mainly to a decline in stroke volume from $60 \pm 5.6$ to $46 \pm 5.4$ $\mathrm{ml}(\mathrm{p}<0.01)$. Heart rate increased in five patients, from $80 \pm 5.6$ to $93 \pm 3.6$ beats per minute. All other parameters were essentially unaffected. Blood gas measurements showed an expected rise in arterial oxygen tension from $80.5 \pm 4.3$ to $419.7 \pm 40.1 \mathrm{~mm} \mathrm{Hg}$ whereas no change occurred in the carbon dioxide tension (Table II).

\section{Discussion}

At the time of measurements during enflurane-pancuronium anaesthesia the cardiovascular effects of the premedication and the succinylcholine used for intubation must be considered minimal. If any lingering effect of the smalt amount of barbiturate used for induction should have influenced our results it should have been in the direction of a cardiovascular depression of direct as well as central sympathetic origin. ${ }^{8}$

Diazepam was chosen for premedication because of its potent sedative and minimal cardiovascular influence (Dalen, et al. 1969). Scopolamine was chosen for its lack of chronotropic effect (Gravenstein and Thornby 1969), ${ }^{10}$ which makes it preferable to atropine when tachycardia should be avoided, as in patients with cardiac valvular disease where digitalis is discontinued at least 24 hours prior to surgery. Pancuronium has been shown to increase arterial pressure and cardiac index during halothane anaesthesia due to an increased pulse rate, believed to be of vagolytic origin (Stoelting 1972). " It is therefore not improbable that the cardiovascular actions of enflurane observed in this study were modified by the simultaneous use of pancuronium. On the other hand, our findings reflect the every-day clinical use of enflurane in patients with cardiac valvular disease. A ten per cent depression was found in cardiac output. This was due to a decline in stroke volume, undoubtedly because of the myocardial depressant actions of enflurane. ${ }^{1.2}$ Our findings in this respect closely resemble those of Marshall, et al. 1971. ${ }^{4}$ In unpremedicated healthy volunteers Levesque, $e t$ al. ${ }^{5}$ found no change in cardiac output after enflurane at an end-tidal concentration of $2.3 \mathrm{per}$ cent. Stroke volume was depressed but pulse rate 
TABLE II

The Change in Blood-Gas Values During Enflurane-Pancuronium Anaesthesia in Patients With Valvular Heart Disease. All Values are Means From Six Patients \pm Standard Errors. A Significant Change is Expressed BY A P-VALUE

\begin{tabular}{|c|c|c|c|}
\hline & $\begin{array}{c}\text { Pre-anaesthetic } \\
\text { values }\end{array}$ & $\begin{array}{l}\text { Anaesthetic } \\
\text { values }\end{array}$ & $\underset{\text { values }}{\mathrm{p}}$ \\
\hline \multicolumn{4}{|l|}{ Systemic artery } \\
\hline $\mathrm{PO}_{2}$ & $80.5 \pm 4.29$ & $419.7 \pm 40.1$ & $<0.001$ \\
\hline $\mathrm{SO}_{2}$ & $0.97 \pm 0.01$ & $1.00 \pm 0.005$ & $<0.01$ \\
\hline $\mathrm{pH}$ & $7.43 \pm 0.02$ & $7.46 \pm 0.02$ & \\
\hline $\mathrm{PCO}_{2}$ & $37.9 \pm 1.29$ & $36.3 \pm 2.26$ & \\
\hline B.E. & $0.73 \pm 0.87$ & $1.17 \pm 0.61$ & \\
\hline St. $\mathrm{HCO}_{3}^{-}$ & $25.12 \pm 0.84$ & $25.38 \pm 0.49$ & $<0.05$ \\
\hline \multicolumn{4}{|c|}{ Pulmonary artery } \\
\hline $\mathrm{PO}_{2}$ & $41.23 \pm 0.76$ & $53.72 \pm 2.99$ & $<0.01$ \\
\hline $\mathrm{SO}_{2}$ & $0.81 \pm 0.06$ & $0.83 \pm 0.04$ & \\
\hline $\mathrm{pH}$ & $7.40 \pm 0.01$ & $7.39 \pm 0.02$ & \\
\hline $\mathrm{PCO}_{2}$ & $45.78 \pm 1.09$ & $45.50 \pm 1.52$ & \\
\hline B.E. & $3.30 \pm 1.34$ & $2.48 \pm 1.01$ & $<0.05$ \\
\hline St. $\mathrm{HCO}_{3}{ }^{-}$ & $26.63 \pm 1.19$ & $26.00 \pm 1.02$ & $<0.05$ \\
\hline
\end{tabular}

increased by 20 beats $/$ min. Systemic resistance and arterial pressure also declined. In our series, pulse rate increased by only 13 beats per minute in mean and, in contrast to the findings of both Levesque, et al. and Marshall, et al., arterial pressure and systemic resistance remained unaffected. Presumably the light level of anaesthesia and the use of pancuronium can account for this difference. It should be noted, however, that Karliczek, et al.$^{12}$ also found enflurane without effect on systemic resistance when added in a concentration of two per cent to the gas flow of a heartlung apparatus.

The haemodynamics of the pulmonary circulation were found unaffected by enflurane. Similar results were obtained by Morr-Strathmann and Lawin. ${ }^{13}$ They found pulmonary arterial pressure to increase from 22 to $26 \mathrm{~mm} \mathrm{Hg}$ during enflurane-pancuronium anaesthesia in man, a change that was probably induced by the change in intrathoracic pressure resulting from the change from spontaneous to controlled ventilation. It is puzzling that we found no increase in wedge pressure, central venous pressure or pulmonary artery pressure as a result of controlled ventilation. All recorded parameters as well as arterial pressure rose markedly during intubation, as has been observed in other studies (Sørensen and Jacobsen ${ }^{14}$ ), but they returned to stable pre-anaesthetic levels at the time of measurement after 15 minutes of enflurane anaesthesia.

Two groups of investigators ${ }^{12.13}$ warn against the use of enflurane in patients with limited car- diac reserve because of marked cardiovascular depression. Morr-Strathmann and Lawin ${ }^{13}$ found two per cent enflurane to depress cardiac output 20 per cent in physical status I patients. These patients who were paralyzed with pancuronium and mechanically ventilated with 50 per cent nitrous oxide-oxygen and enflurane were premedicated with atropine, which possibly could explain why the pulse did not increase during anaesthesia. Karliczek, et al. ${ }^{12}$ found a 25 per cent depression in cardiac output when two per cent enflurane was added to the inspired air of cardiac patients already anaesthetized with "neurolept anaesthesia" and with the pericardium open. The multitude of factors in this study such as premedication, "basal anaesthesia", mechanical ventilation and surgical trauma make the evaluation of cardiovascular changes induced by enflurane itself difficult.

On the basis of our findings we conclude that enflurane-pancuronium anaesthesia in patients with valvular heart diseases is associated with only minimal cardiovascular depression and unchanged pulmonary vascular haemodynamics.

\section{SUMMARY}

The effects of enflurane-pancuronium anaesthesia on cardiovascular haemodynamics were studied before operation in six patients with valvular heart disease. A ten per cent decline in cardiac index and a 20 per cent decline in stroke volume were the only changes observed. Mean arterial, pulmonary arterial, central venous, and 
pulmonary capillary wedge pressures were unaffected, as were systemic vascular resistance and pulmonary vascular resistance.

The authors therefore conclude that enflurane-pancuronium anaesthesia causes only minimal cardiovascular depression in patients with valvular heart disease.

\section{Résumé}

Les effets cardiovasculaires d'une anesthésie à l'enflurane-pancuronium ont été étudiés chez six opérés présentant une pathologie valvulaire. Une diminution de 10 pour cent de l'index cardiaque et de 20 pour cent du volume d'éjection ont été les seules modifications observées. La pression artérielle moyenne, la pression de l'artère pulmonaire, la tension veineuse centrale et la pression capillaire bloquée étaient inchangées, de même que les résistances vasculaires périphériques et pulmonaires.

Les auteurs concluent qu'une anesthésie à l'enflurane-pancuronium ne cause qu'une dépression cardiovasculaire minime chez des patients présentant une atteinte valvulaire.

\section{REFERENCES}

1. Shimosato, S., Sugal, N., Inatsuki, M., \& ETSTEN, B. The effect of Ethrane on cardiac muscle mechanics. Anesthesiology 30; 513 (1969).

2. BROWN, B.R. \& CROUT, J.R. A comparative study of the effects of five general anesthetics on myyocardial contractility. Anesthesiology 34: 236 (1971).

3. Skovsted, P. \& Price, H.L. The effects of Ethrane on arterial pressure, preganglionic sympathe- tic activity and barostatic reflexes. Anesthesiology 36: 257 (1972).

4. Marshazl, B.E., Cohen, P.J., Klingenmaier, C.H., Neigh, J.L., \& Pender, J.W. Some pulnonary and cardiovascular effects of enflurane (Ethrane) anesthesia with varying $\mathrm{PaCO}_{2}$ in man. Brit. J. Anaesth. 43: 996 (1971).

5. Levesque, P.R., Nanagas, V., Shanks, C., \& Shimosato, S. Circulatory effects of enflurane in normocarbic human volunteers. Cand. Anaesth. Soc. J. 2l: 580 (1974).

6. Forrester, J., Ganz, W., Diamond, G., et al. Thermodilution cardiac output determination with a single, flow-directed catheter. Am. Heart J. 83: 306 (1972).

7. DuBors, E.F. Basal metabolism in health and disease. Philadelphia, Lea and Fibiger p. 120 (1927).

8. Skovsted, P., Price, M.L., \& Price, H. The effects of short-acting barbiturates on arterial pressure, preganglionic sympathetic activity and barostatic reflexes. Anesthesiology 33: 10 (1972).

9. Dalen, E., Evans, G.L., Banas, J.S., Brooks, H.L., Paraskos, J.A., \& Dexter, L. The hemodynamic and respiratory effects of diazepam $\left(\right.$ Valium $\left.{ }^{\circledR}\right)$. Anesthesiology 30:259(1969).

10. Gravenstein, J.S.\& Thornby, J.I. Scopolamine on heart rates in man. Clin. Pharmacol. Therap. 10: 395 (1969).

II. Stoelting, R.K. The hemodynamic effects of pancuronium and $\alpha$-tubocurarine in anesthetized patients. Anesthesiology 36: 612 (1972).

12. Karliczek, G., Hempelmann, G., PiepenBRock, S., \& Bürer, F. Die Beeinflussung der Hämodynamik durch Enflurane bei myokardial vargeschädigten Patienten. Anaesthetist 23: 457 (1974).

13. Morr-Strathmann, U. \& Lawin, P. The effects of Ethrane on the hemodynamics of pulmonary circulation. Acta Anesth. Belg. 27, suppl. 245 (1976).

14. Sørensen, M.B. \& Jacobsen, E. Pulmonary hemodynamics during induction of anesthesia. Anesthesiology 46: 246 (1977). 